\title{
Standing in awe of scientific healthcare
}

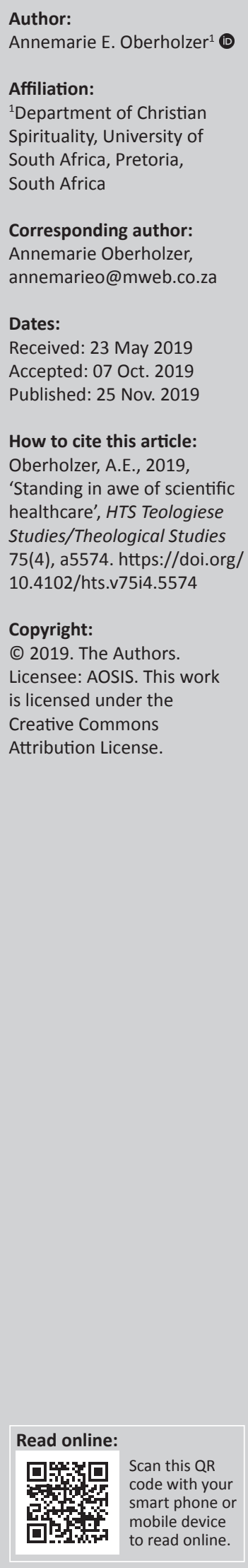

Spirituality and healthcare have been dependant on and supported one another from the earliest times. However, this marriage eventually found itself in stormy waters and parted ways, blaming scientific advances in healthcare for the split. But, as in any broken marriage, the story usually has two sides, and the blame for this split cannot be put squarely on science. In fact, scientific research is now trying to bridge the gap, whereas in the field of Christian spirituality, some are even opposing medical practices and the use of medicine as it could portray a belief in the science of healthcare, as opposed to God. These beliefs only serve to widen the gap between spirituality and healthcare, alienating Christianity from healthcare. If we want to restore the marriage between spirituality and healthcare, it is important to reflect on these beliefs.The purpose of this article is therefore to explore and critically reflect on the relationship between spirituality and healthcare from a Christian perspective. The objective is to identify and address beliefs that are alienating Christianity from healthcare, arguing that, rather than opposing medical practices, we could stand in awe of scientific healthcare.

Keywords: spirituality; science; healthcare; Christian beliefs; awe.

\section{A messy story}

From the earliest times, spirituality and healthcare have been dependant on and supported one another. In prehistoric times, the same person was usually responsible for the physical as well as spiritual care of the tribe. Not many disorders could be cured, and the focus was on spiritual care and comfort measures. The early Christians saw it as their duty to care for the sick, and the first hospitals with this purpose were started by Christians in the 4th century (Ferngren 2009:124). However, this marriage eventually found itself in stormy waters. Amundsen and Ferngren (1982:53) identified four stages of the relationship between spirituality and health to illustrate the decline in this relationship through the ages: (1) medicine as a manifestation or function of religion; (2) medicine and religion as functionally separate but allied and complementary; (3) medicine and religion as simply coexisting and (4) medicine and religion having a hostile and competitive relationship. This hostile relationship can create a lot of tension and is described as 'a messy story' by Cadge (2012:14).

In a previous article, I have pointed out numerous reasons for the split between spirituality and healthcare; these range from the works of the ancient Greek philosophers to the work of Sigmund Freud in the early 1900s (Oberholzer 2017:124-125). These arguments focussed on the changes in and from the scientific field, mostly blaming science for the split between spirituality and healthcare. However, it now seems as if science is doing its part by starting to bridge the gap. Koenig, King and Carson (2012:600) refer to more than 2800 studies focussing on religion or spirituality $(\mathrm{R} / \mathrm{S})$ and health when they conclude that most of these studies found a 'significant positive relationship between R/S involvement and mental or physical health'.

But, as in any broken marriage, the story usually has two sides. The blame for this split cannot be put squarely on scientific developments. As a registered nurse, I have been confronted with many Christian beliefs that were against medical practices and the use of medicine as it could portray a belief in the science of healthcare, as opposed to God. These beliefs are not always outspoken, but rather undercurrents of silent objection. Nevertheless, how can we expect the full cooperation of healthcare staff to incorporate spirituality into healthcare, if the Christian faith often views scientific healthcare with contempt? These beliefs only serve to widen the gap between spirituality and healthcare, alienating Christianity from a healthcare perspective. Cadge (2012:200) explains that doctors blame certain religions, ${ }^{1}$ not spirituality, for causing tension and conflict in their work with patients and added that the doctors highlighted these problems more often than they would 1.Jehovah's witnesses, Orthodox Jews and evangelical Christians were specifically mentioned by name.

Note: Special Collection Gender Justice, Health and Human Development, sub-edited by Cheryl Potgieter (Durban University of Technology). 
refer to religion as being a source of support for their patients. If we want to restore the marriage between spirituality and health, it is important to further investigate these beliefs from a Christian viewpoint.

\section{A view of indifference towards the science of healthcare}

Gaiser (2010:117) agrees that many Christians doubt that Godcan heal through physicians as they believe that God does not need 'modern technology and human skill' to do his work on earth. Another argument often used against healthcare and one that I have heard many times, is that King Asa was condemned to die because, when he became sick, 'he did not seek help from the Lord, but only from the physicians'.2 Another verse often cited to support this argument is Jeremiah 16:5: 'Cursed is the one who trusts in man, who depends on flesh for his strength and whose heart turns away from the Lord'. ${ }^{3}$ According to Ferngren (2009:23), no medical tradition is recorded for the early Hebrews, and the Old Testament refers only to isolated incidences of medical treatment, such as binding wounds (Is 3:7), setting fractures (Ezk 30:21) and the use of healing substances (Is 1:6; Jr 51:8; 8:22). The Israelites did not have healthcare practitioners like those in neighbouring cultures, and Ferngren (2009:23) further explains that the main reason would be 'for fear of religious syncretism', as the Hebrews regarded Yahweh as their only healer. Even today, I have heard people claiming that Exodus 15:26 ('I am the Lord who heals you') implies that only God heals and that it is therefore a sin to take recourse to western medicine.

Ferngren (2009:27) pointed out that two 2nd century Christian writers, Marcion and Tatian, were both believed to be hostile to medicine. Tatian was opposed to the use of drugs, as he believed that it would allow demons to enter the body, and Marcion deleted the reference to Luke as a 'beloved physician' in Colossians 4:14 as he believed that it is not appropriate for Christians to seek the help of physicians. In a recent published conference paper, Lombaard (2018:2) points out that the connection between Luke, the medical man mentioned in Colossians 4, and Luke, the writer of the third gospel, is 'a connection no longer widely accepted in scholarly circles' and can therefore not be used in an argument to promote the acceptance of medical practices into current faith practices. According to Gaiser (2010:170), many commentaries suggest that Mark had the intention to belittle physicians when he remarked that the woman suffering from haemorrhage who approached Jesus had 'suffered a great deal under the care of many doctors and had spent all she had' ${ }^{4}$ It could be argued that this verse further emphasises that doctors do what they do for money and not as an instrument in the hands of God.

Another aspect influencing the way people approach healthcare is grounded in the belief that sin causes illness.

2.2 Chronicles 16:12 (New International Version [Niv])

3.NIV.

4.Mark 5:26 (NIV)
During interviews with representatives from various denominations of the Christian church in South Africa on their view of illness, pain and suffering, a significant number of respondents pointed out that sin could be a reason for illness (Oberholzer 2018:237). Gaiser (2010:197) refers to several instances where the Bible is clear about the relationship between sickness and sin. ${ }^{5}$ Christians often refer to $\sin$ as a reason for illness in a judgemental way. When the mother of a child with disabilities wanted to bring her offerings to the church, she was told that 'You must confess your sin, why the child is disabled, your offering will not be accepted until you confess' (Möller 2012:132). Cadge (2012:160) explains that people often carry a lot of guilt for their own and especially their child's illness, and healthcare staff finds it difficult when they have to address this belief on top of all the other concerns their patients might have.

Attanasi (2012:5) explains that the prosperity doctrine is based on the belief that all of God's people should claim authority over illness, as healing and prosperity are intended for all followers of Christ. In South Africa, a total of $87 \%$ of Christians (90\% of Pentecostals; $85 \%$ of charismatics and $78 \%$ other Christians) expressed the belief that God grants health to those believers who have enough faith (The Pew Forum on Religion and Public Life 2007:30). This could lead to significant spiritual distress in believers if healing does not occur, distress that is often carried over to the healthcare staff as undercurrents of silent objection. Once a family member confessed to me that their child was not healed because of the atmosphere of unbelief created by the doctors and nursing staff in the unit where the child was treated. Kay (2004) cautioned against the tendency to upgrade or downplay faith:

To upgrade faith is to risk condemning the unhealed for their own illnesses and, worse, to make them feel guilty that they even asked for prayer. To downplay faith is to risk pushing healing back behind a barrier of divine inscrutability. (p. 47)

Oberholzer (2018:237) points out that several respondents from various churches in South Africa believe that the devil is responsible for all illness, pain and suffering that people experience. This could lead to the belief that when a doctor performs a certain diagnosis, he or she confirms the work of the devil. At one time, a family member rebuked the devil whom they assumed was speaking through the doctor when he gave them devastating news about their child's prognosis which they did not want to hear. ${ }^{6}$

\section{What about the nursing profession?}

According to Waaijman (2002:99), nursing was also influenced by the medical-science approach, became more professionalised and moved away from embracing it as a calling to serve. Barnum (2011:38) referred to a general split between the nursing profession and spirituality in the late 1950s and early 1960s when nursing became an academic discipline. However, O'Brien (2011:2) explains that the calling to serve has been an

5.Psalm 38:3, 107:17; Micah 6:13.

6.Personal experience of the author. 
integral part of the nursing tradition from the earliest times right up to the conceptualisation of modern medicine in the 21st century. The Nurses' Pledge of Service (SANC 2019), currently used in South Africa, is based on the Nightingale Pledge and is an example of the focus on servanthood. The nursing profession is validated through the healing ministry of Jesus, emphasising the importance of caring for the sick (O'Brien 2011:31), and nursing authors from the 19th and early 20th century also emphasised the 'concepts of service and servanthood', often with a clear biblical association, providing meaningfulness to the role of the nurse as a servant $\left(\mathrm{O}^{\prime} \mathrm{Brien}\right.$ 2011:60-61). O'Brien (2014:11) explains that a nurse can also be described as a 'healer', implying the ability to relieve suffering. According to Macrae (2001:19), Florence Nightingale, who is regarded as the founder of modern nursing science, found a deep sense of meaning in her work as she regarded the facilitation of the healing process as cooperating with God through her work. She encouraged her students to follow the example of Jesus and wrote the following to her nursing students (Nightingale 1914):

What others regard as the service of the sick she may recognise as also the service of God; what others do out of compassion for their maimed fellow-creatures she may do also for the love of Christ. Feeling that God has made her what she is, she may seek to carry on her work in the Hospital as a fellow-worker with God. Remembering that Christ died for her, she may be ready to lay down her life for her patients. (p. 35)

The sixth station of the Cross on the Via Dolorosa in the Old City of Jerusalem is dedicated to a legendary encounter between Jesus and a woman called Veronica. Although not mentioned in the Bible, St Veronica holds great significance for many Christian nurses. It is believed that she was so consumed by compassion and a calling to care for the sick and suffering, that it gave her the courage to step forward, wiping the face of Jesus with her veil, and 'risking the wrath of spear-wielding Roman soldiers, to comfort her injured rabbi' (O'Brien 2011:33). This author further listed several nursing writers who referred to Veronica as a role model for nurses, explaining that she herself 'have always thought of Veronica as a nurse'.

The following excerpt is from a much longer poem in the Catholic Nurse Journal, dedicated to Veronica (Whalley 2012:6):

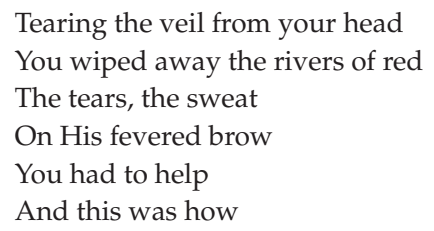

Towards the end of the poem, nurses are encouraged to become like Veronica:

\author{
Reach out with love \\ In whatever way you can \\ With a word, a gesture \\ For it's all in His plan \\ Be just like Veronica \\ So long ago \\ And don't be afraid to let \\ Your feelings show. (Whalley 2012:6)
}

It can therefore be argued that because of biblical and other religious examples, nursing is viewed as a calling for carrying out God's work on earth and serving the sick with compassion and care. But what will happen if we dedicate the same sentiments towards scientific healthcare?

\section{Reflecting further on Christian beliefs in searching for answers ...}

Ferngren (2012:3) starts a chapter on the history of medicine and religion with a statement that, in today's secular society, 'to associate religion with healing seems to be an anachronism that is incompatible with scientific medicine'. However, he soon concludes that religion is as important in today's world as it has been in ancient times, namely 'helping the sick to live with pain and suffering, providing a compassionate care for those who are ill, and offering spiritual consolation to the sick and dying'. However, this does not exclude the role of religion in miracles and supernatural healings in healthcare, as I have personally witnessed. According to The Pew Forum on Religion and Public Life (2007:5), 73\% of Pentecostals, 47\% of charismatics and $32 \%$ other Christians in South Africa indicated that they have 'experienced or witnessed a divine healing of an illness or injury'. Pillay and Moonsamy (2018:207) reported on several cases where hearing loss was healed supernaturally in children with permanent sensorineural hearing loss (SNHL), 'as there is no medical cure available' for this condition.

God does not only heal through miracles. A respondent of the abovementioned study also regarded the restoration of hearing as supernatural healing when it occurred through hearing aids (Pillay \& Moonsamy 2018:211). Gaiser (2010:49) states that if we regard God as our healer, then we should see all 'genuine healing' as coming from God, not only the healings that we cannot explain. He further encourages Christians to point out to the world that all healing (including healing that takes place in a modern hospital) is the work of God and warns that, 'to limit God's healing to the bizarre is to do precisely that: to limit God. Bearing witness to God's healing anywhere and everywhere magnifies God' (Gaiser 2010:57). Swartley (2012:126) encourages us to 'recognise that the two [God as Healer as well as medical resources] blend intrinsically in God's healing design'. Gaiser (2010) urges us to appreciate 'God's graceful presence in the messy world of human affairs' when asking the following question:

What will we make of a God who is willing to risk such misunderstanding, who is willing to work healing through a bronze serpent that can so easily be dismissed as ancient superstition or through a stainless steel scalpel that can so easily be dismissed as atheistic? (p. 46)

Amundsen and Ferngren (1986:51) explained that it has often been argued that, for many centuries, the early Christians objected to secular medicine and instead depended on 'miraculous healing or healing by spiritual means'. However, these authors concluded that the early Christians did not reject physicians and they found 'numerous indications that many early Christians were not hostile to secular medicine 
and the restoration of health by physicians' (Amundsen \& Ferngren 1986:52). Ferngren (2009:23) refuted the 'widespread view that the Hebrews held generally negative views of physicians or medicine' and explained that they might even have taken advantage of medical practitioners from neighbouring cultures such as Egypt, but most of them would have stayed clear from pagan rituals. Gaiser (2010:28-29) explains that, although the Hebrew vocabulary in the Old Testament gives an indication that they did not have a clear understanding of human anatomy, this might be because of the way they see the human body, rather than the way they see God. A dead body was regarded as unclean, and therefore, the practice of removing organs when embalming the dead and/or autopsy of the dead was not tolerated amongst the Hebrews.

Dorff (2003) cited an old rabbinic legend, quoting Rabbi Ishmael and Rabbi Akiva as saying to a farmer that:

Just as if one does not weed, fertilize, and plow, the trees will not produce fruit, and if the fruit is produced but is not watered of fertilized, it will not live but die, so with regard to the body. Drugs and medicaments are the fertilizer, and the physician is the tiller of the soil. (p. 28)

With regards to the widespread belief that sin is responsible for illness, Gaiser (2010:30) further explains that King Asa ${ }^{7}$ was not judged because he consulted physicians, but because he 'did not seek the Lord'.

Waaijman (2002:91) refers to the book of Job as well as John 9:3 when concluding that 'there is no compelling connection between sin and sickness' and explains that 'primitive-religious feelings' will result in viewing illness as a punishment for sin. The relationship between illness and sin has been debated thoroughly by Gaiser (2010:191-206), concluding that a one-sided focus on sin would not give any answers to the problems of this world. However, if the focus remains on forgiveness, it 'invites rather than compels, for it proclaims the biblical God in all God's fullness' (Gaiser 2010:205).

Nursing has many role models who serve to encourage them to follow their calling. However, this is not the case with medical doctors and, as discussed above, they are often viewed in a negative light. During times of illness and suffering, people tend to turn towards spirituality. Christians start to seek God and turn towards the Bible for inspiration and strength. According to the Pew Forum on Religion and Public Life (2007:6), 72\% of Pentecostals and charismatics and $63 \%$ of other Christians indicated that they regard the scripture as the actual word of God and that it should be taken literally. Finding references in the Bible that correlate with their own circumstances is a great source of comfort. It is therefore an attractive practice, not only for patients seeking medical help, but also for healthcare workers, to view Luke, writer of the third gospel, as a medical man. Writings in the interdisciplinary field of spirituality and 7.Two Chronicles 16:12. healthcare, done from a medical perspective, would often include a reference to Luke, writer of the third gospel, as a physician (Ferngren 2009:105; Koenig et al. 2012:19). One of the required courses included in the spirituality and health curricula of medical schools in Brazil is called The Gospel according to Luke and its relationship to health and medicine (Lucchetti et al. 2012:5).

Hobart (1882) made a very long and intensive linguistic study of the Gospel of Luke and the Acts of the Apostles and concluded that they were written by a medical man. However, this work was refuted by Cadbury (1920) who explained that:

$[W]$ hile he (Hobart) shows most diligently that the words he catalogues are employed by the medical writers, he does not show that they are not employed by other writers with no professional training. (p. 41)

Cadbury (1920:46) further admits that Luke was a 'well educated person' and therefore used more 'technical terms than a less educated person'. This debate was going back and forth, and Weissenrieder (2003:1) explains that scholars in the field of theology regarded further investigation into the healing narratives described by Luke of 'minimal importance', as the focus should be on the healing actions of Jesus. However, he added that Luke's understanding of and focus on illness 'can be made plausible against a background of ancient medicine' (Weissenrieder 2003:2). Swartley (2012:126) agrees that Luke emphasizes the healing ministry of Jesus because of his background as a physician. Ferngren (2009:194) concluded that 'while the linguistic evidence for the use of medical terminology is inconclusive, there is no reason to doubt the Colossian identification of Luke as a physician'. Paul sent greetings to the people of Colossae in the name of 'our dear friend Luke, the doctor', ${ }^{8}$ implying that he had a close relationship with a physician, and according to Gaiser (2010:34), the designation of Luke serves to bring honour to the profession of a physician. The Presbyterian minister E.R. Beadle addressed students in Philadelphia in 1865 on 'The sacredness of the Medical Profession' and based his presentation on Colossians 4:14 when urging students to be a preacher as well as a practitioner in order to be godly like Luke (Smylie 1986:217).

Although Luke is the only physician mentioned in the Bible, Schulze (2005:235-239) compiled a list of 194 Christian physicians during the first 8 centuries, four of which were from as early as the 1st century (including Luke). According to Schulze (2005:154), the medical occupation counted amongst some of the most popular occupations of the early Christians. Dally (2003:17) commented that up until the mid-19th century, doctors in the western world were usually Christians who 'used theological arguments alongside their scientific reasoning'.

It should be noted that the Hippocratic Oath distinguished between internists and surgeons when proclaiming that 'Iwill not use the knife, not even on sufferers from stone, 8.Collossians 4:14 (NIV). 
but will draw in favour of such men as are engaged in this work' (Berdine 2015:31). Berdine explains that the physicians of those days can be compared to the internists of today, whereas today's surgeons were more likely to 'descend from the ancient order of barbers' and added that physicians and barbers were two distinct disciplines in competition with each other.

Gaiser (2010:170) argues that instead of interpreting Mark 5:26 as that Mark had the intention to belittle physicians as mentioned earlier, it should rather be interpreted as that the woman 'at one time had money to spend on physicians', which could also have included a leader of the synagogue. According to Van Wyk (2011:2), Philipp Melanchthon (1497-1560), Rector of the University of Wittenberg during Martin Luther's lifetime, combined anatomy and medical science with religion. The apocryphal book Sirach, included in Catholic and Orthodox Bibles but omitted in protestant Bibles, is very clear about honouring physicians:

Honor physicians for their services, for the Lord created them; for their gift of healing comes from the Most High, and they are rewarded by the king. The skill of physicians makes them distinguished, and in the presence of the great they are admired. The Lord created medicines out of the earth, and the sensible will not despise them ... God's works will never be finished; and from him health spreads over all the earth ... There may come a time when recovery lies in the hands of physicians, for they too pray to the Lord that he grant them success in diagnosis and in healing, for the sake of preserving life. ${ }^{9}$

Cadge (2012:156) talks about an 'invisible awareness' of spirituality amongst healthcare staff and explains that 'many of the ways religion and spirituality are present in hospitals are invisible on the surface, rarely the subject of public discussion'. Maybe it is time to bring into the open discussions on spirituality and healthcare, addressing the invisible awareness of spirituality amongst healthcare staff together with the undercurrents of silent objection so that we can explore what it is to stand in awe of scientific healthcare.

\section{Standing in awe of scientific healthcare}

According to Ostow (2007:34), we are in awe when 'we are moved by percepts that transcend the usual range of perceptible phenomena', but it can also be so overwhelming that it creates fear in us (p. 43).

Schneider (2009:179) defines awe as 'two distinct yet overlapping modes of consciousness - the mode of wonder (e.g., allure, fascination, and adventure) and the mode of unsettlement (e.g., anxiety, apprehension, and puzzlement)'. According to Halstead (2006:26), awe can imply being in 'solemn admiration and reverence, whether directed towards a superior or divine being or in response to something vast or splendid in the natural world'. If the incredible advances in scientific healthcare are taken into account, it is not difficult to admire and to stand in awe of scientific healthcare.

9.Sirach 38:1-4; 8 and 13-14 (NRSV-CI) - New Revised Standard Version; Catholic Interconfessional.
But then again, to stand in awe is a choice, and does not happen automatically. The way in which we perceive phenomena, depends on how we interpret it. We can learn a lot from children, who have the ability to stand in awe of life. Because of their limited understanding, they can experience most of life as mysterious. However, as they grow, they learn that there is an answer to everything, 'and displace or even repress the true mysteriousness of existence' (Hay \& Nye 2006:72). These authors further ask the question whether children's perception of mystery does not 'arise from as profound an experience as those of the contemplative philosopher or the theologian?'

A mother's womb is no longer a 'secret place' as proclaimed by the Psalmist, ${ }^{10}$ and sonar pictures of week-old foetuses are often shared on social media for the world to see. Google allows us to gain a basic understanding about scientific healthcare, so that it is no longer a mysterious experience. However, this should not cause us to lose our sense of wonder towards scientific healthcare. When we see God in those working in scientific healthcare and more specifically the physicians, we can acknowledge them as instruments in God's hand and hold them in high esteem.

Schneider (2009:114) had an interview with E. Mark Stern, an emeritus professor in psychology, and discussed the role that awe played during his own journey with heart bypass surgery and cancer. Mark made the following comments with regard to his surgeon:

As a surgical patient, he [the surgeon] was in my bosom and I (even under anesthesia) was radically responsive. I too played my role. Awe-fullness/being the brunt of intimidation, overwhelmed (that's awe too) and then awestruck and in harmony with him as if we were two in one. Ultimate intimacy. Much of my cure was my reparation, my animation - and with my cancer my 'belly dance' in tune with my surgeon's capacity to dance in my body. (Schneider 2009:114)

This reminds me of a little boy who came to hospital for a short surgical procedure. His mother was literally dancing around the room, engaging him in an exciting discovery of his hospital room and all the equipment.

Engaging his sense of awe at everything new, she managed to change the situation from what could have been a very scary experience for a 5-year-old boy, into an exciting adventure, helping him to cope with the experience comfortably.

Gaiser (2010:58) warns that when we only acknowledge something as the work of God when we cannot understand it, we are widening the gap between science and religion, making science the enemy, limiting the work of God on earth and restraining our own understanding of the magnitude of God. As Schneider (2009:180) explains, 'awe can bring a sense of validation where there formerly was estrangement'.

10.Psalm 139:15 (Niv). 


\section{One final warning ...}

Standing in awe of healthcare does not imply worshipping the god of scientific healthcare. Benson and Stark (1996) mentioned that this was the trend in the 1900s, and warned that it would lead to a 'spiritual crisis':

... [T] he god of science we once believed had the power to stamp out disease and delay death's eventual toll is proving inadequate. Scientific medicine may have transformed and reconfigured hope for our ancestors, amazed as they were that human intelligence and scientific methods could wrest from God what was previously considered a divine decision - who would live and who would die. (p. 107)

Regarding scientific healthcare as the be-all and end-all of life, will disappoint. According to Waaijman (2002:91), 'primitivemedical enlightenment minds' will focus only on medicalbiological causes. The trend to 'overmedicalise' has recently been debated at length and can be defined as when 'treatments that are not always necessary or of no use at all are prescribed too often' (Worley 2017:177). Kaczmarek (2018:120) describes it as when something has been 'wrongly recognised as a medical problem' or 'simply misinterpreted as a problem in the first place'. People often want quick-fixes and prefer taking medication rather than changing their habits or lifestyles to prevent disorders. As Kaczmarek (2018:127) concluded, 'the tools offered by medicine may not be optimal'.

Advocating for an 'awe-based' view of life, Schneider (2009:8) encourages readers to embrace 'both the wonders of existence and the human responsibility to engage, discern, and ethically respond to those wonders'.

\section{Acknowledgements}

\section{Competing interests}

The author has declared that no competing interest exists.

\section{Author(s) contributions}

I declare that I am the sole author of this research article.

\section{Ethical consideration}

This article followed all ethical standards for a research without direct contact with human or animal subjects.

\section{Funding information}

This research received no specific grant from any funding agency in the public, commercial or not-for-profit sectors.

\section{Data availability statement}

Data sharing is not applicable to this article as no new data were created or analysed in this study.

\section{Disclaimer}

The views and opinions expressed in this article are those of the author and do not necessarily reflect the official policy or position of any affiliated agency of the author.

\section{References}

Amundsen, D.W. \& Ferngren, G.B., 1982, 'Medicine and religion: Pre-Christian antiquity', in M.E. Marty \& K.L. Vaux (eds.), Health/medicine and the faith traditions: An inquiry into religion and medicine, pp. 53-92, Fortress Press, Philadelphia, PA.

Amundsen, D.W. \& Ferngren, G.B., 1986, 'The early Christian tradition', in R.L. Numbers \& D.W. Amundsen (eds.), Caring and curing: Health and medicine in the western religious traditions, pp. 40-64, Macmillan, New York.

Attanasi, K., 2012, 'Introduction: The plurality of prosperity theologies and Pentecostalisms', in K. Attanasi \& A. Yong (eds.), Pentecostalism and prosperity: The socioeconomics of the global charismatic movement, pp. 1-12, Palgrave MacMillan, New York.

Barnum, B.S., 2011, Spirituality in nursing: The challenges of complexity, 3rd edn., Springer, New York.

Benson, H. \& Stark, M., 1996, Timeless healing: The power and biology of belief, Fireside, New York.

Berdine, G., 2015, 'The Hippocratic oath and principles of medical ethics', The Southwest Respiratory and Critical Care Chronicles 3(9), 28-32. https://doi. org/10.12746/swrccc.v3i9.185

Cadbury, H.J., 1920, The style and literary method of Luke, Harvard University Press, Harvard.

Cadge, W., 2012, Paging God: Religion in the halls of medicine, University of Chicago Press, Chicago, IL.

Dally, A., 2003, The trouble with doctors: Fashions, motives and mistakes, Robson Books, London.

Dorff, E.N., 2003, Matters of life and death: A Jewish approach to modern medical ethics, The Jewish Publication Society, Philadelphia, PA.

Ferngren, G.B., 2009, Medicine and health care in early Christianity, John Hopkins University Press, Baltimore, MD.

Ferngren, G.B., 2012, 'Medicine and religion: A historical perspective', in M. Cobb C.M. Puchalski \& B. Rumbold (eds.), Oxford textbook of spirituality in healthcare, pp. 3-10, Oxford University Press, Oxford.

Gaiser, F.J., 2010, Healing in the Bible: Theological insight for Christian ministry, Bake Academic, Michigan.

Halstead, J.M., 2006, 'Awe and wonder', in E.M. Dowling \& W.G. Scarlett (eds.), Encyclopedia of religious and spiritual development, pp. 26-27, Sage, Thousand Oaks, CA.

Hay, D. \& Nye, R., 2006, The spirit of the child, revised edn., Jessica Kingsley, London.

Hobart, W.K., 1882, The medical language of St. Luke: A proof from internal evidence that 'the gospel according to Luke' and 'the acts of the Apostles' were written by the same person, and that the writer was a medical man, University Press, Dublin.

Kaczmarek, E., 2018, 'How to distinguish medicalization from over-medicalization?', Medicine, Health Care and Philosophy 22(1), 119-128. https://doi.org/10.1007/ s11019-018-9850-1

Kay, W.K., 2004, 'Introduction: Healing', in W.K. Kay \& A.E. Dyer (eds.), Pentecostal and charismatic studies, pp. 47-51, SCM Press, London.

Koenig, H.G., King, D.E. \& Carson, V.B., 2012, Handbook of religion and health, 2nd edn., Oxford University Press, New York.

Lombaard, C.J.S., 2018, 'Something old, something new... The unfolding link between spirituality and health', in A. de la Porte, N. Joubert \& A.E. Oberholzer (eds.) Wholeness in health care: Proceeds of the 2nd Biennial conference on spirituality and health care, pp. 1-15, Cambridge Scholar, Newcastle.

Lucchetti, G., Lucchetti, A.L.G., Espinha, D.C.M., De Oliveira, L.R., Leite, J.R. \& Koenig H.G., 2012, 'Spirituality and health in the curricula of medical schools in Brazil', BMC Medical Education 12(78), 1-8. https://doi.org/10.1186/1472-6920-12-78

Macrae, J.A., 2001, Nursing as a spiritual practice: A contemporary application of Florence Nightingale's views, Springer, New York.

Möller, C., 2012. The experiences of people with disabilities in faith communities: A social work perspective, MA thesis, University of South Africa, Pretoria.

Nightingale, F., 1914, Florence Nightingale to her nurses: A selection from Miss Nightingale's addresses to probationers and nurses of the Nightingale School as St. Thomas's Hospital, MacMillan and Co., London.

Nurses' Pledge of Service (SANC), 2019, Nurses' pledge, viewed 13 March 2019, from www.sanc.co.za/aboutpledge.htm.

O'Brien, M.E., 2011, Servant leadership in nursing: Spirituality and practice in contemporary health care, Jones \& Bartlett, Sudbury.

O'Brien, M.E., 2014, Spirituality in nursing: Standing on holy ground, 5th edn., Jones \& Bartlett, Burlington, NJ.

Oberholzer, A.E., 2017, 'Relocating religion back to the hospital: A focus on children's spiritual care in healthcare', Journal of Theology for Southern Africa 157(March), 120-134.

Oberholzer, A.E., 2018, 'The role of Christian churches in rendering spiritual support to children in healthcare', in A. de la Porte, N. Joubert \& A.E. Oberholzer (eds.) Wholeness in health care: Proceeds of the 2nd Biennial conference on spirituality and health care, pp. 227-245, Cambridge Scholar, Newcastle.

Ostow, M., 2007, Spirit, mind and brain: A psychoanalytic examination of spirituality and religion, Columbia University Press, New York.

Pillay, D. \& Moonsamy, S., 2018, 'Supernatural healing: Emotional reactions to hearing loss in the South African context', in A. de la Porte, N. Joubert \& A.E. Oberholzer (eds.), Wholeness in health care: Proceeds of the 2 nd biennial conference on spirituality and health care, pp. 207-226, Cambridge Scholar, Newcastle. 
Schneider, K.J., 2009, Awakening to awe: Personal stories of profound transformation, Jason Aronson, Lanham, MD.

Schulze, C., 2005, Medizin und Christentum in Spätantike und frühem Mittelalter: Christliche Ärzte und ihr Wirken, Mohr Siebeck, Tübingen.

Smylie, J.H., 1986, 'The reformed tradition', in R.L. Numbers \& D.W. Amundsen (eds.), Caring and curing: Health and medicine in the western religious traditions, pp. 204-239, Macmillan, New York.

Swartley, W.M., 2012, Health, healing and the church's mission: Biblical perspectives and moral priorities, IVP Academic, Downers Grove, IL.

The Pew Forum on Religion and Public Life, 2007, Spirit and power: A 10-country survey of pentecostals, The Pew Forum, Washington, DC.
Van Wyk, I.W.C., 2011, 'Finding a place for Jesus as healer in reformed mission in Africa', HTS Teologiese Studies/Theological Studies 67(1), 1-8. https://doi. org/10.4102/hts.v67i1.864

Waaijman, K., 2002, Spirituality: Forms, foundations, methods, Peeters, Leuven.

Weissenrieder, A., 2003, Images of illness in the gospel of Luke: Insights of ancient medical texts, Mohr Siebeck, Tübingen.

Whalley, G., 2012, 'Poem to St Veronica', Catholic Nurse Journal, Christmas edn. viewed 11 March 2019, from www.catholicnurses.org.uk

Worley, L, 2017 'Choosing wisely: The antidote to overmedicalisation', The Lancet: Respiratory Medicine 5(3), 177-178. https://doi.org/10.1016/S2213-2600(17) 30054-1 